\title{
A GAZDASÁGI ÉS INNOVÁCIÓS POTENCIÁLOK HATÁSÁRA LÉTREJÖVÖ CSALÁDI KAPCSOLATOK, VISZONYOK MODERN TÍPUSAINAK INTERDISZCIPLINÁRIS VIZSGÁLATA
}

\author{
Kriston Edit \\ tudományos segédmunkatárs, Miskolci Egyetem, Civilisztikai Tudományok Intézete, Polgári Jogi Tanszék \\ 3515 Miskolc, Miskolc-Egyetemváros, e-mail: jogedit@uni-miskolc.hu
}

\begin{abstract}
Absztrakt
A tanulmány lényege az EFOP-3.6.1-16-2016-00011 azonositó számú, „Fiatalodó és megújuló Egyetem Innovativ Tudásváros, A Miskolci Egyetem intelligens szakosodást szolgáló intézményfejlesztése" elnevezésü projektben végzett egyéni kutatómunka összefoglalása. Ahogy az a tanulmány címéböl is látható, interdiszciplináris megközelitésböl került elemzésre a családi kapcsolatok jogi szabályozásának rendszere, elötérbe helyezve a gazdaságban és a társadalomban végbemenö innovációs folyamatok leképzödését és hatásait.
\end{abstract}

Kulcsszavak: család, élettárs, társadalmi innováció

\begin{abstract}
I summarize in this article my research work in the project EFOP-3.6.1-16-2016-00011, "Younger and Renewing University - Innovative Knowledge City - institutional development of the University of Miskolc aiming at intelligent specialisation". As the title of this article shows, I analyzed the legal definition of family, and the legal effect of new family connections - like de facto partnerships or registered partnerships - in the light of the economic and social challenges and changes of the present.
\end{abstract}

Keywords: family, de facto partnership, innovation of society

\section{Bevezetés}

„Magyarország védi... a családot, mint a nemzet fennmaradásának alapját.” - hangzik Alaptörvényünk egyik rendelkezése, mely szerint a családot, mint jogintézményt az állam köteles védelemben részesíteni elsősorban a jog eszközein keresztül, illetve más egyéb módokon is. A jogvédelem tárgya tehát látszólag egyértelmü, ugyanakkor mélyebb vizsgálódások által arra a következtetésre juthatunk, hogy ennek az egyszerünek tünő elöírásnak a gyakorlati értelmezése nem is olyan könnyü feladat. Az ugyanis, hogy mit is kell pontosan a család megnevezés alatt értenünk, azaz milyen viszonyokra kell az államnak kiterjesztenie a jogvédelmet, számos kérdést vet fel.

A világ folyamatos és rendkívül dinamikus változásokon megy keresztül, a társadalmi átalakulások, a társadalmi kapcsolatok teljesen más képet festenek ma, mint egykoron. A változás fó jellegzetessége annak gyorsasága, hiszen napról napra újabb és újabb társadalmi viszonyok kialakulásának lehetünk szemtanúi. Nincs ez másképp a család megítélésével sem. Ha megkérdezünk valakit, hogy mit ért a család fogalma alatt a lehető legeltérőbb válaszlehetőségekkel találjuk szembe magunkat. Ugyanezt tapasztaljuk, ha a tudomány oldaláról közelítjük meg a kérdését. Ahány tudományág, annyi válaszlehetőség merül fel, ráadásul egy-egy tudományterületen belül sincs egyetértés a fogalmi alapvetéseket illetően. 
A családjog területét szabályozó normák komplex rendszert alkotnak, aminek köszönhetően szintén nehézséget jelent az egységes jogi fogalom megalkotása vagy megállapítása. Ebből adódóan a kutatás célja az volt, hogy kísérletet tegyen a család, illetve a családi jogviszonyok fogalmi rendszerének feltárására, illetve vizsgálat tárgyát képezte a 2014. március 15-én hatályba lépett új normaanyag. A Polgári Törvénykönyv ugyanis a hatálybalépésével jelentősen kibővítette a családjog törvényi elöírásait, legfőképpen a párkapcsolatok jogi megítélését illetően. A házasság, mint tradícionális forma mellett, helyet kapnak ma már a társadalmi igényekhez igazodóan az egyéb párkapcsolati formák és ennek megfelelően jogvédelmük is megalapozásra került. Ugyanakkor ezen formák - bár már hosszú ideje a mindennapjaink részét képezik - joggyakorlata most van igazán alakulóban, a jogalkalmazás felkészülni igyekszik a várható kihívásokra. Különösen igaz ez a de facto élettársai kapcsolatok jogi szabályozására, ez a párkapcsolati forma ugyanis korábban is megtalálható volt a magánjogi szabályozásban, ugyanakkor a jogalkotó igyekezett a családjogon kívül eső, szerződéses kapcsolattá redukálni azt. A jelenlegi szabályozás azonban új felfogást igyekszik tükrözni, amely szükségszerúen meg fog jelenni a joggyakorlatban is. Erre tekintettel a kutatásomban arra is nagy hangsúlyt fektettem, hogy a de facto élettársak szabályanyagának lehetséges értelmezési módjait vizsgáljam.

\section{A család fogalmának interdiszciplináris vizsgálata}

A polgári kor szellemisége és eszméi olyan folyamatokat indítottak be Európában, melyek csak később, a mai modern jogrendszerekben fejtik ki hatásukat. Ezek az eszmék természetesen a család megítélését is jelentősen befolyásolják. A történelem folyamán nagyon hosszú ideig a házasság, illetve a törvényen vagy biológiai kapcsolaton alapuló leszármazás jelentette a családi kapcsolatok bázisát. Ez azonban a modern társadalmak vonatkozásában már nem helytálló megállapítás. A polgárosodás, valamint a jogegyenlőség eszméinek hatására kialakultak az embert megillető alapjogok, melyeknek modern megítélését nagyon hosszú jogérvényesítési harc előzte meg. Ezen alapjogok egyike a magánélethez és családi élethez való jog, melynek modernkori értelmezése jelentősen átalakította a család jogi megítélését.

Önmagában azonban a jogi elemzés nehézségeket vet fel, éppen ezért szükségesnek tartottam más tudományágak eredményeinek vizsgálatát is. Az elemzéseim középpontjába a szociológia megállapításait helyeztem, álláspontom szerint ugyanis ez az a tudományterület, ami segítheti a jogi értelmezések ellentmondásainak feloldását. Erre tekintettel két tanulmányban ${ }^{1}$ is foglalkoztam a szociológiai családfogalom vizsgálatával, valamint összehasonlítottam a jogi meghatározások lehetséges tartalmával.

A vizsgálódásaim alapján arra a következtetésre jutottam, hogy a szociológiai értelemben vett család funkcionális szempontból történő definiálása hatékonyabb válaszként szolgálhat a fennálló társadalmi helyzetnek megfelelő jogi meghatározás kialakításához. A tradicionális szemlélet nem alkalmas a modern család strukturális jellemzőinek pontos leírására, hiszen továbbra is a házasság és a leszármazás, mint hagyományos értékek prioritását helyezi a középpontba. ${ }^{2} \mathrm{~A}$ házasság és a megszokott családmodell fenntarthatósága ma is elsőbbséget élvez, az állam igyekszik a hagyományos értékek

\footnotetext{
${ }^{1}$ Kriston, E.: A család és ami mögötte van - A szociológia válasza a fogalomalkotás tükrében In: Szabó, M. (szerk.): 2018 Doktoranduszok Fóruma. A Miskolci Egyetem Állam és Jogtudományi Kar szekciókiadványa, Miskolc, pp. 63-67.

Kriston, E.: A család fogalma a társadalmi innováció sürüjében, különös tekintettel a jogi és szociológiai megközelitésre, Publicationes Universitatis Miskolcinensis Series Juridica et Politica Tomus XXXVI 2018/2. szám. pp. 396-407.

${ }^{2}$ V.ö.: Cseh-Szombathy, L.: Családi viszonyok In: Andorka, R., Kolosi, T., Vukovich, Gy. (szerk.): Társadalmi riport, TÁRKI, Budapest, 1990. pp. 487-500.
} 
irányába terelni a mai nemzedékeket általában több-kevesebb sikerrel. A társadalmi szemléletváltás azonban éppen a fiatalabb korosztályban figyelhető meg. Manapság egyre többen gondolják úgy, hogy nincs szükség házasságkötésre ahhoz, hogy az életüket együtt élhessék le, a „csak egy darab papír”ként való értelmezés térhódítása egyre inkább észlelhető. A modern társadalmi viszonyok nem türik meg a házasság intézményének kizárólagosságát, mint a társas kapcsolatok egyeduralkodó csoportját, így szükség van a partnerkapcsolatok más formáinak elismerésére is. ${ }^{3}$

A szociológia funkcionális látásmódja azt sugallja felénk, hogy az ott meghatározott tartalmi elemek képesek lépést tartani ezekkel a modern társadalmi változásokkal, így akár alapul is szolgálhatnak a családfogalom jogi megközelítésének modernizálásához. Ezt támasztja alá az is, hogy a jogirodalomban megjelentek olyan álláspontok, mely szerint a jogi értelemben vett család alapja mindenképpen a szociológiai fogalom kell, hogy legyen, mert az képes valamennyi kapcsolatrendszert lefedni. ${ }^{4}$

Véleményem szerint az Alaptörvény L) cikkének értelmezése nem fedi le teljeskörüen a családi kapcsolatok egészét, így mindenképpen szükséges egy általánosabb, generálisabb családfogalom ki-

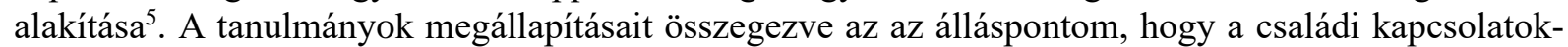
ban két tényezőnek van kiemelt jelentősége. Ebből az egyik a felek között fennálló érzelmi közösség megléte, amely nem követeli meg feltétlenül, hogy az érintettek valamilyen párkapcsolati formát válasszanak és abba kerüljenek besorolásra. ${ }^{6}$ A másik fontos tényező a gazdasági kapcsolat - és nem a gazdasági közösség - megléte. Ha megvizsgáljuk ugyanis a családtagok közötti vagyoni viszonyokat, egyértelmü, hogy a közös gazdálkodás nem követelmény a családi kapcsolat megállapíthatósága szempontjából. Példaként említhető a házastársak vagy élettársak közötti teljes vagyonelkülönítés, de akár a pénzbeli rokontartási kötelezettség is ide sorolható. Ezekben az esetekben ugyanis nem feltétlenül fordul elö közös vagyoni érték, amelyre a családtagok mindegyike igényt tarthatna. A gazdasági kapcsolat sokkal alaposabb megfogalmazás, jobban kifejezi azt, hogy a felek közötti gazdasági függés valamilyen formában meg kell, hogy valósuljon. Szintén fontos az is, hogy a családi kapcsolat kizárólag természetes személyek egymás közötti viszonyában értelmezhető, jogi személyek esetén fel sem merülhet.

Mindezt értékelve és összegezve a család jogi fogalmának meghatározására az alábbi javaslatot tettem: A család természetes személyek között létrejövö társadalmi viszony, amelyben a felek között érzelmi közösség és gazdasági kapcsolat áll fenn.

\section{A bejegyzett élettársi kapcsolat és a de facto élettársi kapcsolat}

Európa államaiban a XX. század végén megjelent az igény az azonos nemü párok jogi helyzetének elismerésére és védelmére. Elsőként 1989-ben Dániában született meg az azonos nemüekre vonatkozó jogi szabályozás, majd ezt követte 1993-ban Norvégia, 1994-ban Svédország, 1996-ban Izland, végül 2001-ben Finnország. ${ }^{7}$ Nem tétlenkedett azonban Európa többi állama sem, a 2000-es évek elején folyamatos jogi elismerést és támogatást kapott az azonosnemúek együttélése. A végcél a házassággal

\footnotetext{
${ }^{3}$ Kriston, E.: Az élettársak megítélése az alkotmányjog és a polgári jog szempontjából, Publicationes Universitatis Miskolcinensis, Sectio Juridica et Politica, Tomus XXXIV. 2016/1. szám, pp. 232-233.

${ }^{4}$ Lásd részletesebben: Barzó, T.: A magyar család jogi rendje, Patrocínium Kiadó, Budapest 2017. pp. 36-39.

${ }^{5}$ V.Ö.: Drinóczi, T., Zeller, J.: A házasság és a család alkotmányjogi helyzete, Jura, 2006/1. szám, pp. 16-22.

${ }^{6}$ Bár a jogirodalom a házasság, a bejegyzett élettársi kapcsolat és a de facto élettársi kapcsolat között tesz egyértelmüen különbséget, álláspontom szerint ugyanakkor kialakulhatnak olyan érzelmi közösségek is - akiket családnak kell tekintenünk viszont - akik egyik kategóriába sem sorolhatóak.

${ }^{7}$ Szeibert, O.: Élettársi kapcsolat és regisztrált partnerkapcsolat Svédországban és Norvégiában - együttmüködés az északi jogkör országai között, Polgári Jogi Kodifikáció, 2006/2. szám 12.
} 
egyenrangú jogintézményként történő elfogadás volt, ugyanakkor az eredmény sokkal differenciáltabb lett. ${ }^{8}$ Kezdetben az államok csak úgy voltak hajlandóak legjobb esetben is elfogadni az azonos nemüek partnerkapcsolatát, ha a házasság intézményétől elkülönített, külön jogszabály eltérő jogkövetkezményeket alkalmazott. Később azonban ez a merevnek mondható hozzáállás oldódni látszott és ma már elmondható, hogy Európa számos állama biztosítja az azonos nemüek számára a tradícionális jogintézménnyel lényegében azonos házasságot és ez által a családkénti elismerést. ${ }^{9}$ A fennmaradó államok többsége szintén biztosítja a jogvédelem valamely fajtáját az azonos nemü pároknak, ugyanakkor nem biztosít a házassággal egyenértékü jogkövetkezményeket. ${ }^{10}$ Vannak azonban olyan európai államok is, amelyek a társadalmi nyomás ellenére továbbra is ragaszkodnak a tradícionális értékekhez és nem ismerik el az azonos nemúek párkapcsolatát. ${ }^{11} \mathrm{~A}$ témához kapcsolódóan a kutatásaim során részletesen vizsgáltam az azonos nemüek hazai és nemzetközi szabályozásának helyzetét és megállapításaimat egy újabb tanulmányban foglaltam össze. ${ }^{12}$

A kutatásaim másik jelentős részét a de facto élettársi kapcsolat új hazai szabályozásának vizsgálata tette ki. Tekintettel arra, hogy a téma nagyobb volumenü kutatást és elemzést igényelt, ennek megfelelően több tanulmányban, összefoglaló szakcikk-sorozatként prezentáltam az eredményeimet. ${ }^{13}$

A 2013. évi V. törvénynek mindenképpen fontos vívmánya a de facto élettársi kapcsolat normaanyaágnak bővülése, a megszületett eredmény azonban a korábbiakhoz hasonlóan továbbra is szükszavú maradt. A Ptk. élettársi törvényes vagyonjogként olyan rendszert teremt, amely sok hasonlóságot mutat a házastársak esetében házassági vagyonjogi szerződésben alkalmazható közszerzeményi rendszerrel. ${ }^{14}$ Fontos azonban annak a kihangsúlyozása, hogy a két rendszer között jelentős különbségek is megfigyelhetőek, amelynek okaként egyértelmüen az élettársi kapcsolat szerződésként való kezelése jelölhető meg. A kodifikációs munkálatok során olyan normarendszer kiépítése volt a cél,

\footnotetext{
${ }^{8}$ Az Európai Családjogi Bizottságának nemzeti jelentései: http://ceflonline.net/informal-relationships-reportsby-jurisdiction/ Letöltve: 2021.01.05.

9 A következő országok ismerik el az azonos nemüek házasságát: Belgium, Dánia, Anglia, Wales, Írország, Finnország, Franciaország, Luxemburg, Hollandia, Norvégia, Portugália, Skócia, Spanyolország, Svédország és Németország. A soron következő állam Ausztria, ahol 2019-ben lép hatályba az azonos nemüek házasságát biztosító jogszabályi módosítás - az osztrák Legfelső Bíróság G 258-259/2017-9 számú döntése.

${ }^{10}$ Ilyen például hazánk is, ahol jelenleg külön törvényben került szabályozásra a bejegyzett élettársi kapcsolat. Példaként említhető még Horvátország, Észtország, Csehország de a legfrissebb állapotok szerint Olaszország is, ahol 2016-ben került bevezetésre a regisztrált élettársi kapcsolat.

${ }^{11}$ Ilyen jelenleg Románia, Lettország vagy Szlovákia, de akár Oroszország is megemlíthető.

${ }^{12}$ Kriston, E.: A család megitélése Európában, különös tekintettel az azonos nemü párok helyzetére In: Szabó, M. (szerk.): Studia Iurisprudentiae Doctorandorum Miskolciensium (Miskolci Doktoranduszok Jogtudományi Tanulmányai) Tomus 18. Bíbor Kiadó, Miskolc, 2019. pp. 85-96.

${ }^{13}$ Kriston, E.: A de facto élettársi kapcsolat elmélete és gyakorlata - fogalmi nehézségek (I. rész) Advocat, (Miskolc) XXI. 2018/4. szám, pp. 3-7.

Kriston, E.: A de facto élettársi kapcsolat elmélete és gyakorlata - 2. rész: Az élettársak közötti törvényes vagyonjogi rendszer, Advocat, 2019/1. szám, pp. 13-20.

Kriston, E.: A de facto élettársi kapcsolat elmélete és gyakorlata - 3. rész: A de facto élettársi tartás, Advocat, 2019/2. szám, pp. 18-26.

Kriston, E.: A de facto élettársi kapcsolat és törvényen alapuló vagyoni viszonyaik, Ügyvédek Lapja, 2019/9-10. szám

${ }^{14}$ Szeibert, O.: Az élettársi kapcsolat In: Wellmann, Gy. (szerk.): Polgári Jog. Kötelmi Jog. - Az új Ptk. magyarázata VI./VI. HVG-ORAC, Budapest, 2013. p. 420.
} 
amely szándékoltan nagyobb autonómiát biztosít az élettársak számára, ${ }^{15}$ ugyanakkor felszámolja az ítélkezési gyakorlatban előkerülő, divergáló értelmezést eredményező kérdéseket. ${ }^{16}$

A Ptké. 50. §-a szerint, ha e törvény eltérően nem rendelkezik, a Ptk. hatálybalépésekor fennálló kötelmekkel kapcsolatos és a Ptk. hatálybalépését követően keletkezett tényekre, megtett jognyilatkozatokra valamint az ezekből eredeztethető, további megtett nyilatkozatokra a Ptk. hatálybalépése elött hatályos jogszabályok rendelkezéseit kell alkalmazni. ${ }^{17} \mathrm{~A}$ Ptk. élettársi törvényes vagyonjogi szabályai tehát kizárólag a Ptk. hatálybalépését követően keletkezett élettársi jogviszonyokra alkalmazhatóak, ami azt eredményezi, hogy a bíróságoknak sokáig párhuzamosan kell két, merőben különböző szabályrendszert alkalmaznia, az élettársi kapcsolatok ugyanis kétség kívül tartós jellegü jogviszonyok. A joggyakorlatban ezért lassan üti fel a fejét a hatályos szabályanyag értelmezésének lehetősége, aminek egyenes következménye, hogy egyelöre csak elméleti szinten vitatható a kérdés. Kétségtelen azonban, hogy a joggyakorlatnak kiemelt jelentősége lesz, hiszen megfelelő iránymutatás elsősorban innen várható.

A tanulmányok célja a szükszavú jogalkotói produktum értelmezéséből eredő nehézségek szemléltetése volt. Véleményem szerint vannak olyan elemei a hatályos normaanyagnak, ahol a megfelelő jogértelemzés képes a jogalkotó szándékának megfelelő vitarendezést eredményezni, más területeken viszont szükséges lenne a jogalkotói beavatkozás is.

Fontosnak tartom annak hangsúlyozását, hogy az élettársi kapcsolat - bár elsősorban szerződéses és nem kifejezetten családjogi kapcsolatként lett elhelyezve a normaanyagban - részét kell, hogy képezze a Kőrös András által a „család viszonyok bonyolult szövedékének” 18 nevezett jogviszonyrendszernek, és mindenképpen megkülönböztetett, a családjogi szabályozáshoz még inkább közelítő értelmezést kell, hogy nyerjen a jövőben.

\section{A családi kapcsolatokat érintő egyéb kutatások}

A kutatás komplex jellegéből adódóan a fentebb megjelölt, hangsúlyosabb témakörökön túlmenően további, a kutatási témát érintő elemzéseket is végeztem. Az egyéb kutatások szintén a családjog szabályozását és gyakorlatát érintették elsősorban két témakör, a házasság és a családtagok szerződéses jogviszonyainak analízisére építve.

A házasság jogintézménye az egyik leghagyományosabb alapokon nyugvó eleme a modern jogrendszereknek, ugyanakkor tradicionális jellege ellenére a változás ezt sem kerülheti el. A társadalmi szemléletváltás által indukált modern szemlélet magát a házasságot is áthatja, ami szükségszerủen azt eredményezi, hogy a jól kidolgozott részletes értelmezés ellenére újból és újból felülvizsgálják a jogintézményt. A változások előidéző egyik ok, amivel a kutatásaimban foglalkoztam, a mesterséges intelligencia és a robotika térnyerése. Első olvasásra úgy tünhet, hogy igencsak futurisztikus elképzelésről van szó, ugyanakkor már találkozunk olyan társadalmi igényekkel, amelyek előrevetítik egy ilyen jogi probléma felmerülését, éppen ezért egy tanulmány erejéig történeti kontextusba helyezve vizsgáltam a

\footnotetext{
15 Éreztetve ezzel azt, hogy az élettársi kapcsolat bár a házasság alternatívája, ugyanakkor a házasság dominanciáját és családjogban elfoglalt elsődleges helyét nem válthatja fel. Éppen ezért a joghatások között is szükséges a differenciáltság hangsúlyozása a házasság javára.

${ }^{16}$ Szeibert (2013) 420.

17 2013. évi CLXXVII. törvény a Polgári Törvénykönyvről szóló 2013. évi V. törvény hatálybalépésével összefüggő átmeneti és felhatalmazó rendelkezésekről (a továbbiakban: Ptké.) 50. § (1) bekezdés

${ }^{18}$ Körös, A.: Alapelvek In: Körös, A. (szerk.).: Az új Ptk. magyarázata. Családjog. III/VI. HVG-ORAC, Budapest, 2013. p. 30.
} 
házasság, mint jogintézmény múltbéli, jelenlegi és lehetéséges jövőbeni megítélését. ${ }^{19} \mathrm{~A}$ mesterséges intelligencia jogi vonatkozásai számos tanulmányban kerültek analizálásra. Az egyik ilyen irányvonal szerint a fejlett intelligenciával rendelkező robotok rendkívüli módon hasonlítanak az emberekre, ami kétféle eredményre vezethet: a fejlett intelligenciával rendelkező egyedek jogértelmezési szempontból egy tekintet alá esnek majd a természetes személyekkel a hasonlóság mértékére tekintettel. Ez azonban rendkívül drasztikus megoldásnak tekinthető, ami számos egyéb kérdést vet fel. A jogirodalomban inkább elfogadott megoldás a robotokra vonatkozó önálló, sui generis szabályozás kidolgozása, ami a személyek jogán belül hasonlóan a jogi személyekhez, elkülönítetten, egyfajta új kategóriaként kerülne elhelyezésre. ${ }^{20}$ Ez utóbbi esetben felmerül a kérdés a hogy egy ilyen sajátos megoldás hatással lehet-e a házasság jogi megítélésére? Álláspontom szerint magát a szabályozási környezetet nem feltétlenül szükséges megváltoztatni, ugyanakkor a jogértelmezésben egyértelmüen egy tágabb értelmezés kaphat helyet. Ez azonban még csak elméleti síkon vitatható, a közeljövőben ugyanis semmiképpen sem várható a jogi szabályozás ezirányú megváltoztatása.

A kutatások másik irányát a családtagok szerződéses viszonyai képezték. A szerződési szabadság érvényesülése fontos részét képezi a családtagok közötti szerződéses viszonyoknak. A családtagok közötti privátautonómia nehezen türi akár a jogalkotói, akár a más módon történő beavatkozást, ugyanakkor adódnak olyan helyzetek, amik szükségessé teszik azt. A szerződési szabadság korlátai komplex rendszert képeznek a családtagok közötti szerződésekben. Ennek oka, hogy a korlátok által biztosított védelem két irányba hat: segítséget jelent egyfelől a kiszolgáltatott helyzetben lévő családtagnak, másrészt védelmet biztosít a családtagokkal ügyleti kapcsolatban álló harmadik személyeknek. A komplexitás másik fontos oka a jogterületeken való áthatás, hiszen a családjogi megállapodások elsősorban a családjog, másrészt viszont a kötelmi jog hatálya alá tartoznak. Ebből adódóan találunk olyan korlátokat, amelyek tisztán családjogi normákból erednek, illetve olyanokat is, amik kötelmi természetủek, ugyanakkor a családi jogviszonyhoz idomulnak. Tisztán családjogi korlátként értékelhetők a Családjogi Könyv elején elhelyezett alapelvek, különös tekintettel a méltányosság és a gyengébb fél védelmének szem előtt tartására. A tanulmány ${ }^{21}$ célja az volt, hogy bemutassa milyen komplex rendszert is alkotnak a családtagok között létrejövő szerződéses viszonyok és hogy a bennük érvényesülő szerződési szabadságnak - legföképpen a tartalomszabadságnak - hogyan szab gátat a jogi szabályozásban megjelenő családjogi alapelvek összessége.

\footnotetext{
${ }^{19}$ Kriston, E.: Házasságot minden(ki)nek? - Innovatív megoldások és társadalmi reflexiók a házasság jogintézményében. Innovatív magánjogi megoldások a társadalmi-gazdasági haladás szolgálatában (Tanulmánykötet), Magánjogot Oktatók Egyesülete, Miskolc, 2020. pp. 130-136.

${ }^{20}$ Koch, B. A.: Product Liability 2.0 - Mere Update or New Version? In: Lohsse, S., Shulze, R., Staudenmayer, D. (szerk.): Liability for Artificial Intelligence and the Internet of Things. Baden-Baden, Germany, Nomos, 2019. p. 115 .

Az Európai Unió maga is foglalkozik a kérdéssel, sőt egy állásfoglalásában elsőként tette közzé a „electronic personality (e-personality)” azaz elektronikus személyiség koncepcióját. Később azonban az állásfoglalásban foglaltakat visszavonta. - European Parliament 2014-2019TEXTS ADOPTEDP8_TA (2017)0051Civil Law Rules on Robotics European Parliament resolution of 16February 2017 with recommendations to the Commission on Civil Law Rules on Robotics (2015/2103(INL))

${ }^{21}$ Kriston, E.: A családjogi alapelvek tartalomformáló hatása a családtagok közötti megállapodásokban, Publicationes Universitatis Miskolcinensis, Sectio Juridica et Politica, Tomus XXXVIII. 2020/1. szám, pp. 358-374.
} 


\section{Köszönetnyilvánítás}

A cikkben ismertetett kutató munka az EFOP-3.6.1-16-2016-00011 jelü „Fiatalodó és Megújuló Egyetem - Innovatív Tudásváros - a Miskolci Egyetem intelligens szakosodást szolgáló intézményi fejlesztése" projekt részeként - a Széchenyi 2020 keretében - az Európai Unió támogatásával, az Európai Szociális Alap társfinanszírozásával valósul meg.

\section{Irodalom}

[1] Barzó, T.: A magyar család jogi rendje, Patrocínium Kiadó, Budapest, 2017.

[2] Cseh-Szombathy, L.: Családi viszonyok In: Andorka, R., Kolosi, T., Vukovich, Gy. (szerk.): Társadalmi riport, TÁRKI, Budapest, 1990.

[3] Drinóczi, T., Zeller, J.: A házasság és a család alkotmányjogi helyzete, Jura, 2006/1. szám

[4] Koch, B. A.: Product Liability 2.0 - Mere Update or New Version? In: Lohsse, S., Shulze, R., Staudenmayer, D. (szerk.): Liability for Artificial Intelligence and the internet of things, BadenBaden, Germany, Nomos, 2019. https://doi.org/10.5771/9783845294797-97

[5] Körös, A.: Alapelvek In: Körös, A. (szerk.).: Az új Ptk. magyarázata. Családjog. III/VI. HVGORAC, Budapest, 2013.

[6] Kriston, E.: Az élettársak megitélése az alkotmányjog és a polgári jog szempontjából, Publicationes Universitatis Miskolcinensis, Sectio Juridica et Politica, Tomus XXXIV. 2016/1. szám

[7] Szeibert, O.: Élettársi kapcsolat és regisztrált partnerkapcsolat Svédországban és Norvégiában - együttmüködés az északi jogkör országai között, Polgári Jogi Kodifikáció, 2006/2. szám

[8] Szeibert, O.: Az élettársi kapcsolat In: Wellmann, Gy. (szerk.): Polgári Jog. Kötelmi Jog. $-A z$ új Ptk. magyarázata VI./VI. HVG-ORAC, Budapest, 2013. 